\title{
Views and Attitudes of Intercultural Awareness in Chinese Teaching and Learning in Shanxi Provincial Universities Context
}

\author{
Junqing Wang \\ College of International Education and Communication, Shanxi University, Taiyuan, China
}

\begin{abstract}
The perceptions of academic staffs and overseas students to the significance of intercultural awareness in Chinese teaching/learning as foreign language were studied to provide suggestions for enhancing their intercultural communication competence in the context of Shanxi Provincial universities. The participants of 273 students and 52 staffs took part in the questionnaire and 25 of them accepted semi-structured interview. The combination of qualitative and quantitative analysis indicated a significant correlation between intercultural experience, length of Chinese teaching/learning and the enthusiasm in target language involved programs, regardless of age or gender. The attitudes to cultural diversity, misunderstanding even conflicts unavoidably existed in these universities influenced target language and culture mastery. This study suggested the promotion of intercultural awareness among staffs as well as students was important to help international students take advantage of opportunities available at campus or beyond to improve their effective intercultural communication. And much more intercultural strategies, including more positive learning environment, appropriated curriculum, further exploration, concentrated on improving target language proficiency and extending cultural experience in Chinese classes should be implemented to motivate students' intercultural enthusiasm and competence.
\end{abstract}

Index Terms-Chinese teaching/learning as foreign language, target language and culture mastery, intercultural awareness, cultural diversity, intercultural communication competence

\section{INTRODUCTION}

Nowadays, Globalization is influencing universities worldwide through market competition. The growth of international education over recent 5 years has provided China an opportunity to develop international market (Australia Bureau of Statistics, 2013). Internationalization of education has become a significant development in Chinese universities. From 2010 to 2015, international students in China rose from 265,090 to 397,635 (150 \%).

As we all know, learning a foreign language is one of the best way to make people conscious of outside world and culture. With 'the silk Road Economic Belt and the $21^{\text {st }}$-Centrtury Maritime Silk Road (B\&R)' initiative of China in 2014, more and more international students from nearly 60 countries in Eurasia participated in on-line, in-country and face-to-face Chinese teaching modes. Any country or person planed to operate globally in accordance with current global trends can benefit socially, economically and personally (Chinese National Development and Reform Commission, 2015). China universities offer short-term or long term programs to provide overseas students an opportunity to learn Chinese in a natural immersion environment.

However, because of different social backgrounds, social systems, and customs, people have difficulties in understanding and communicating with each other (Petrakis, 2013). This is also a problem that has troubled both teachers and learners. It is well known that teaching or learning a foreign language cannot be only linguistic skills like phonology, morphology, vocabulary or syntax (Forsman, 2012). Language learning and target cultures cannot realistically be separated. Mak (2010) asserts language learning is a deep, conceptual activity which involves explicit analysis of language and culture.

Therefore, intercultural awareness is required for a foreign language learner to promote intercultural communication competence (Leask, 2009). Bodycott and Lai (2012) mention that foreign language learners should be aware to actively intermingle their own culture with target culture. Colvin et al (2012) points out intercultural awareness helps learners broaden mind, increase tolerance and achieve cultural empathy and sensitivity. Intercultural awareness is a consciousness and an ability to put intercultural conceptions into practice in an real-time cross-cultural context (Baker, 2011). Thus, intercultural awareness is a learning process in which we become adapt to the target language and cultural situations and principles (Leung \& Chiu, 2010).In foreign language teaching/learning, an awareness of target language and culture needs to be carefully considered. Otherwise, the potential cross-cultural communication problems arise from lacking mutual untranslatable speech or behavior. There is no question that successful integration of culture could contribute significantly to target language teaching/learning (Matsumoto \& Yoo, 2006).

Therefore, this study was to investigate the perceptions of academic staff members and overseas students towards the significance of intercultural awareness in Chinese teaching/ learning in Shanxi Provincial universities, including Shanxi 
University, Taiyuan Science \& Technology University, Shanxi Agriculture University, Taiyuan Normal University, and Shanxi Finance and Economy University. The following research objectives were set out: to investigate staff and students' perceptions towards the significance of intercultural awareness in Chinese teaching/learning; to provide some suggestions for enhancing intercultural communication competence in Chinese teaching and learning in Shanxi Provincial tertiary educational context

\section{Methodology}

This study employed combination of qualitative and quantitative research methods. There were 273 students and 52 academic staff members from the universities of Shanxi Province took part in the research. Participants were given informed consent and the right to withdraw at any stage. They were assured of their anonymity and the destruction of the recordings five years after reporting of this research. All these strategies ensured the participants could give responses confidently, and thus the investigation outcomes are credible.

Data collection methods including questionnaire (see in Appendices I, II) and semi-structured interview (see in Appendices III), which were concerned about participants' views and attitudes towards the significance of intercultural awareness in Chinese teaching/learning as foreign language. The questionnaire employed during Phase 1 adopted "Likert Scale" format (Likert, 1932). Interviews were guided by one set of five questions for staffs/students (Phase 2). The completed questionnaires were conducted in two ways: paper-based (given face-to-face) and web-based (Potential participants were contacted by email explaining the research objectives and inviting them to participate in). The email also contained an attachment of questionnaire. During Phase 1, a 40-items questionnaire was distributed to 325 academic staffs and oversea students. Table1 shows the details of the participants.

TABLE1

DETAILED INFORMATION OF PARTICIPANTS INVOLVED IN THIS STUDY

\begin{tabular}{|c|c|c|c|c|c|}
\hline \multirow{2}{*}{\multicolumn{2}{|c|}{ Items }} & \multicolumn{2}{|c|}{ Staff participants } & \multicolumn{2}{|c|}{ Student participants } \\
\hline & & Count & $\%$ of total & Count & $\%$ of total \\
\hline \multirow{2}{*}{ Gender } & Male & 17 & 32.7 & 112 & 41.0 \\
\hline & Female & 35 & 67.3 & 161 & 59.0 \\
\hline \multirow{5}{*}{ Age } & 18-22 years & 0 & 0.0 & 41 & 15.0 \\
\hline & 23-30 years & 5 & 9.6 & 102 & 37.4 \\
\hline & $31-40$ years & 33 & 63.5 & 72 & 26.4 \\
\hline & $41-50$ years & 15 & 28.8 & 53 & 19.4 \\
\hline & 51 years + & 9 & 17.3 & 5 & 1.8 \\
\hline \multirow{4}{*}{$\begin{array}{l}\text { Years of teaching/learning } \\
\text { Chinese as foreign language }\end{array}$} & $0-1$ year & 1 & 1.9 & 57 & 20.9 \\
\hline & $1-3$ years & 4 & 7.7 & 103 & 37.7 \\
\hline & $3-5$ years & 16 & 30.8 & 75 & 27.5 \\
\hline & 5 years + & 31 & 59.6 & 38 & 13.9 \\
\hline
\end{tabular}

Data gathered from this stage were analyzed with Statistical Packages for Social Science (SPSS) version 19.0. During Phase 2, semi-structured interviews were organized among 6 staffs and 19 students. The interviews were recorded using a portable digital recorder and transcribed, analyzed predominantly using CA approach (Paul et al, 2006).

Since sample data were not normally distributed, Kruskal-Wallis test was used in this study to determine whether statistically significant differences existed among four independent variables (occupation, gender, age, length of teaching/studying). If significant differences were found using Kruskal-Wallis tests, Mann Whitney U tests was then conducted to identify which group had significant differences $(p \leqq 0.05)$

\section{RESULT AND DATA ANALYSIS}

\section{A. Result and Quantitative Data Analysis}

The descriptive statistics of the participants' responses in terms of 3 themes: personal intercultural experience, views of intercultural awareness, intercultural awareness and language teaching and learning were analyzed. And descriptive statistics of the participants' responses were showed by six sub-themes in this section.

1. Views and attitudes about China and world

As seen from Table 2, all participants had a positive view in relation to these items. The participants view China as a culturally diverse society (Q6). They also agreed intercultural awareness played an important role in China (Q7) and international students were an important source of this multicultural awareness (Q8). Such a high degree of agreement signified no further tests were necessary. 
TABLE 2

PARTICIPANTS' RESPONSES ON VIEWS ABOUT CHINA AND THE WORLD

\begin{tabular}{|c|c|c|c|c|c|c|c|}
\hline \multicolumn{2}{|l|}{ Items } & SA & $\mathrm{A}$ & NS & $\mathrm{D}$ & SD & Total \\
\hline \multirow{2}{*}{$\begin{array}{l}\text { Q6. China is a nation of cultural } \\
\text { diversity now. }\end{array}$} & count & 135 & 169 & 15 & 6 & 0 & 325 \\
\hline & $\%$ of total & 41.5 & 52.1 & 4.6 & 1.8 & 0 & 100 \\
\hline \multirow{2}{*}{$\begin{array}{l}\text { Q7. Intercultural awareness is } \\
\text { important to China. }\end{array}$} & count & 202 & 114 & 2 & 6 & 0 & 325 \\
\hline & $\%$ of total & 62.3 & 35.2 & 0.6 & 1.9 & 0 & 100 \\
\hline \multirow{2}{*}{$\begin{array}{l}\text { Q8. International students are an } \\
\text { important source of intercultural } \\
\text { awareness. }\end{array}$} & count & 74 & 181 & 36 & 33 & 1 & 325 \\
\hline & $\%$ of total & 22.7 & 55.6 & 11.0 & 10.1 & 0.3 & 100 \\
\hline
\end{tabular}

2. Personal intercultural experience

Generally speaking, most of the participants agreed that they enjoy traveling to other countries (16.3\% disagreed), appreciated food from other countries (20.7\% disagreed), and interacting with people from different cultural backgrounds (3.8\% disagreed).The low degree of disagreements (Table3) suggested that there was no need for further investigations about this topic.

TABLE 3

PARTICIPANTS' RESPONSES ON PERSONAL INTERCULTURAL EXPERIENCE

\begin{tabular}{|l|l|l|l|l|l|l|l|}
\hline Items & SA & A & NS & D & SD & Total \\
\hline \multirow{2}{*}{$\begin{array}{l}\text { Q9. I like to interact with people from } \\
\text { different cultural backgrounds. }\end{array}$} & count & 68 & 153 & 51 & 25 & 28 & 325 \\
\hline \multirow{nyyyyyyy}{*}{$\begin{array}{l}\text { Q10. I like eating food from other } \\
\text { countries. }\end{array}$} & count total & 20.8 & 47.2 & 15.7 & 7.8 & 8.5 & 100 \\
\hline \multirow{2}{*}{\begin{tabular}{l} 
Q11. I like to travel overseas. \\
\cline { 2 - 8 }
\end{tabular}} & \% of total & 28.3 & 21.1 & 29.9 & 12.5 & 8.2 & 100 \\
\cline { 2 - 8 } & count & 165 & 147 & 1 & 10 & 2 & 325 \\
\hline
\end{tabular}

3. Aspects of intercultural awareness

Table4 demonstrated that participants held positive views on all of the statements in this section. At least $75 \%$ of participants agreed each item. Similarly, the high degree of agreement suggested no need for further investigations and more tests.

TABLE 4

PARTICIPANTS' RESPONSES ON ASPECTS OF INTERCULTURAL AWARENESS

\begin{tabular}{|c|c|c|c|c|c|c|c|}
\hline \multicolumn{2}{|l|}{ Items } & SA & A & NS & $\mathrm{D}$ & SD & Total \\
\hline \multirow{2}{*}{$\begin{array}{l}\text { Q12. Intercultural awareness enriches one's } \\
\text { life. }\end{array}$} & count & 94 & 166 & 56 & 6 & 2 & 325 \\
\hline & $\%$ of total & 28.9 & 51.2 & 17.3 & 1.9 & 0.7 & 100 \\
\hline \multirow{2}{*}{$\begin{array}{l}\text { Q13. Intercultural awareness widens one's } \\
\text { worldview. }\end{array}$} & count & 90 & 165 & 56 & 7 & 3 & 321 \\
\hline & $\%$ of total & 27.6 & 50.9 & 17.3 & 2.1 & 0.8 & 98.7 \\
\hline \multirow{2}{*}{$\begin{array}{l}\text { Q14. Intercultural awareness enhances } \\
\text { understanding of one's own culture. }\end{array}$} & count & 119 & 153 & 45 & 4 & 4 & 325 \\
\hline & $\%$ of total & 36.7 & 47 & 13.7 & 1.3 & 1.3 & 100 \\
\hline \multirow{2}{*}{$\begin{array}{l}\text { Q15. Intercultural awareness enhances world } \\
\text { peace. }\end{array}$} & count & 145 & 119 & 32 & 16 & 10 & 321 \\
\hline & $\%$ of total & 44.5 & 36.6 & 9.8 & 4.9 & 3.1 & 98.9 \\
\hline \multirow{2}{*}{$\begin{array}{l}\text { Q16. Intercultural awareness is hard to } \\
\text { develop. }\end{array}$} & count & 106 & 128 & 29 & 49 & 10 & 323 \\
\hline & $\%$ of total & 32.7 & 39.6 & 8.9 & 15.3 & 2.8 & 99.3 \\
\hline \multirow{2}{*}{$\begin{array}{l}\text { Q17. Travel enhances intercultural } \\
\text { awareness. }\end{array}$} & count & 121 & 140 & 27 & 11 & 26 & 325 \\
\hline & $\%$ of total & 37.1 & 43.2 & 8.2 & 3.4 & 8.1 & 100 \\
\hline \multirow{2}{*}{$\begin{array}{l}\text { Q18. Interacting with migrants enhances } \\
\text { intercultural awareness. }\end{array}$} & count & 127 & 145 & 9 & 11 & 33 & 325 \\
\hline & $\%$ of total & 39.1 & 44.7 & 2.7 & 3.3 & 10.2 & 100 \\
\hline \multirow{2}{*}{$\begin{array}{l}\text { Q19. Interacting with oversea students } \\
\text { enhances intercultural awareness }\end{array}$} & count & 110 & 129 & 62 & 9 & 13 & 323 \\
\hline & $\%$ of total & 33.8 & 39.7 & 19.2 & 2.7 & 4.1 & 99.5 \\
\hline \multirow{2}{*}{$\begin{array}{l}\text { Q20. The internet plays an important role in } \\
\text { intercultural awareness. }\end{array}$} & count & 155 & 124 & 24 & 9 & 13 & 325 \\
\hline & $\%$ of total & 47.8 & 38 & 7.3 & 2.7 & 4.1 & 99.9 \\
\hline
\end{tabular}

Notes:The reason why total percentage of some items were not 100 was because participants did not put check-mark on any option of these items.

4. Intercultural awareness and language teaching/earning

Further, as indicated in the Table5, they generally agreed that there were benefits resulting from the inclusion of cultural components in a language course. The agreement percentage of each item was range from $74 \%$ to $97 \%$, and the disagreement percentage of each was lower than $5 \%$. Once again, the high level of agreement to statements was achieved. 
TABLE 5

PARTICIPANTS' RESPONSES ON INTERCULTURAL AWARENESS AND LANGUAGE TEACHING/LEARNING

\begin{tabular}{|c|c|c|c|c|c|c|c|}
\hline \multicolumn{2}{|l|}{ Items } & SA & $\mathrm{A}$ & NS & $\mathrm{D}$ & SD & Total \\
\hline \multirow{2}{*}{$\begin{array}{l}\text { Q21. Learning Chinese involves learning its } \\
\text { culture. }\end{array}$} & count & 201 & 114 & 6 & 0 & 3 & 324 \\
\hline & $\%$ of total & 61.9 & 35.2 & 1.7 & 0 & 0.9 & 99.7 \\
\hline $\begin{array}{l}\text { Q22 Cultural component provides meaningful } \\
\text { context for Chinese language course. }\end{array}$ & count & 107 & 141 & 54 & 17 & 2 & 321 \\
\hline \multirow{2}{*}{$\begin{array}{l}\text { Q23. Cultural components enhances students' } \\
\text { motivation towards target language. }\end{array}$} & count & 130 & 181 & 10 & 1 & 2 & 323 \\
\hline & $\%$ of total & 39.9 & 55.7 & 3.1 & 0.2 & 0.5 & 99.4 \\
\hline $\begin{array}{l}\text { Q24. Cultural component promotes students' } \\
\text { curiosity about Chinese language. }\end{array}$ & count & 97 & 158 & 30 & 1 & 11 & 297 \\
\hline \multirow{2}{*}{$\begin{array}{l}\text { Q25. Cultural component does not impede } \\
\text { students' Chinese acquisition. }\end{array}$} & count & 149 & 96 & 43 & 12 & 5 & 303 \\
\hline & $\%$ of total & 45.8 & 29.4 & 13.1 & 3.7 & 1.5 & 93.5 \\
\hline
\end{tabular}

Notes: The reason why total percentage of some items were not 100 was because participants did not put check-mark on any option of these items.

\section{Intercultural awareness in course design}

It was found from Table6 that the participants mostly agreed that culture should be part of language course and integrated into language teaching $(87.7 \%)$. They commonly accepted that students in a language program should be introduced to a native speaker (56.5\%), and textbooks in a language program should be written by native speakers of the target language too $(59.6 \%)$. A majority $(98.9 \%)$ of the participants strongly believed that part from textbooks, there were other useful resources for teaching in language program. However, whether or not foreign students should be involved in a language program, the participants' views were divided: $39.4 \%$ agreed, but $32 \%$ disagreed, and $20.8 \%$ were not sure. Also, interestingly, about compulsory professional course, half agreed (48.9\%), but another half (45.7\%) disagreed that they should be taught in English. Therefore, further analysis was conducted to identify factors that influenced participants' views on these questions. The Kruskal-Wallis Test or Mann-Whitney U test was chosen to determine whether these questions were associated with participants' occupation, gender, age group, and length of Chinese teaching/studying as foreign language.

TABLE 6

PARTICIPANTS' RESPONSES ON ASPECTS OF INTERCULTURAL AWARENESS

\begin{tabular}{|c|c|c|c|c|c|c|c|}
\hline \multicolumn{2}{|l|}{ Items } & SA & $\mathrm{A}$ & NS & $\mathrm{D}$ & SD & Total \\
\hline \multirow{2}{*}{$\begin{array}{l}\text { Q26. Culture should be part of Chinese language } \\
\text { course. }\end{array}$} & count & 125 & 160 & 12 & 15 & 0 & 312 \\
\hline & $\%$ of total & 38.6 & 49.1 & 3.6 & 4.7 & 0.1 & 96.1 \\
\hline \multirow{2}{*}{$\begin{array}{l}\text { Q27. Culture should be integrated into Chinese } \\
\text { teaching. }\end{array}$} & count & 151 & 145 & 11 & 8 & 3 & 319 \\
\hline & $\%$ of total & 46.6 & 44.7 & 3.5 & 2.5 & 0.8 & 98.1 \\
\hline \multirow{2}{*}{$\begin{array}{l}\text { Q28. Students in a language program should be } \\
\text { introduced to native Chinese speaker. }\end{array}$} & count & 118 & 66 & 45 & 51 & 32 & 312 \\
\hline & $\%$ of total & 36.2 & 20.3 & 13.9 & 15.8 & 9.7 & 95.9 \\
\hline \multirow{2}{*}{$\begin{array}{l}\text { Q29. Foreign students should be introduced to a } \\
\text { Chinese language program. }\end{array}$} & count & 56 & 72 & 68 & 66 & 38 & 300 \\
\hline & $\%$ of total & 17.3 & 22.1 & 20.8 & 20.4 & 11.6 & 92.2 \\
\hline \multirow{2}{*}{$\begin{array}{l}\text { Q30. Textbooks in a language program should be } \\
\text { written by native Chinese speakers. }\end{array}$} & count & 99 & 127 & 26 & 37 & 9 & 298 \\
\hline & $\%$ of total & 30.5 & 29.1 & 17.9 & 11.3 & 2.8 & 91.6 \\
\hline \multirow{2}{*}{$\begin{array}{l}\text { Q31. Translation should be avoided in language } \\
\text { teaching. }\end{array}$} & count & 77 & 71 & 61 & 80 & 16 & 305 \\
\hline & $\%$ of total & 23.7 & 21.9 & 18.7 & 24.6 & 4.9 & 93.8 \\
\hline \multirow{2}{*}{$\begin{array}{l}\text { Q32. Apart from textbooks, there are other resources } \\
\text { for teaching in Chinese language program. }\end{array}$} & count & 186 & 135 & 1 & 3 & 0 & 325 \\
\hline & $\%$ of total & 57.3 & 41.6 & 0.2 & 0.8 & 0 & 99.9 \\
\hline \multirow{2}{*}{$\begin{array}{l}\text { Q33. Some compulsory professional courses should } \\
\text { be taught in English, not Chinese. }\end{array}$} & count & 64 & 95 & 6 & 66 & 83 & 313 \\
\hline & $\%$ of total & 19.8 & 29.1 & 1.7 & 20.3 & 25.4 & 96.3 \\
\hline
\end{tabular}

Notes: The reason why total percentage of some items were not 100 was because participants did not put check-mark on any option of these items.

It was found from Table6 that the participants mostly agreed that culture should be part of language course and integrated into language teaching $(87.7 \%)$. They commonly accepted that students in a language program should be introduced to a native speaker (56.5\%), and textbooks in a language program should be written by native speakers of the target language too $(59.6 \%)$. A majority $(98.9 \%)$ of the participants strongly believed that part from textbooks, there were other useful resources for teaching in language program. However, whether or not foreign students should be involved in a language program, the participants' views were divided: $39.4 \%$ agreed, but $32 \%$ disagreed, and $20.8 \%$ were not sure. Also, interestingly, about compulsory professional course, half agreed (48.9\%), but another half (45.7\%) disagreed that they should be taught in English. Therefore, further analysis was conducted to identify factors that influenced participants' views on these questions. The Kruskal-Wallis Test or Mann-Whitney U test was chosen to determine whether these questions were associated with participants' occupation, gender, age group, and length of Chinese teaching/studying as foreign language.

6. Personal experience in a language program 
TABLE7

PARTICIPANTS' RESPONSES ON ASPECTS OF INTERCULTURAL AWARENESS

\begin{tabular}{|c|c|c|c|c|c|c|c|}
\hline \multicolumn{2}{|l|}{ Items } & SA & $\mathrm{A}$ & NS & $\mathrm{D}$ & SD & Total \\
\hline \multirow{2}{*}{$\begin{array}{l}\text { Q34. The Chinese language program I have } \\
\text { taught/studied is practical. }\end{array}$} & count & 99 & 124 & 44 & 24 & 9 & 300 \\
\hline & $\%$ of total & 30.6 & 38.1 & 13.4 & 7.3 & 2.9 & 92.3 \\
\hline \multirow{2}{*}{$\begin{array}{l}\text { Q35. The Chinese language program I have } \\
\text { taught/studied pays much attention to the culture. }\end{array}$} & count & 122 & 127 & 31 & 17 & 23 & 319 \\
\hline & $\%$ of total & 37.5 & 39.1 & 9.4 & 5.2 & 7.1 & 98.3 \\
\hline \multirow{2}{*}{$\begin{array}{l}\text { Q36. The Chinese language program I taught/studied } \\
\text { deals adequately with intercultural awareness. }\end{array}$} & count & 85 & 136 & 61 & 22 & 15 & 319 \\
\hline & $\%$ of total & 26.2 & 41.9 & 18.8 & 6.8 & 4.5 & 98.2 \\
\hline \multirow{2}{*}{$\begin{array}{l}\text { Q37. The Chinese language program I have } \\
\text { taught/studied helps me to appreciate other cultures. }\end{array}$} & count & 102 & 82 & 36 & 44 & 24 & 288 \\
\hline & $\%$ of total & 31.4 & 25.2 & 11.2 & 13.6 & 7.3 & 88.7 \\
\hline \multirow{2}{*}{$\begin{array}{l}\text { Q38. The Chinese language program I taught/studied } \\
\text { inspires me to interact with people of different } \\
\text { cultures. }\end{array}$} & count & 119 & 181 & 8 & 7 & 11 & 325 \\
\hline & $\%$ of total & 36.5 & 55.7 & 2.4 & 2.1 & 3.3 & 100 \\
\hline \multirow{2}{*}{$\begin{array}{l}\text { Q39. The Chinese language program I have } \\
\text { taught/studied enhances my intercultural awareness. }\end{array}$} & count & 148 & 104 & 19 & 16 & 15 & 302 \\
\hline & $\%$ of total & 45.6 & 32.1 & 5.7 & 4.9 & 4.5 & 92.8 \\
\hline
\end{tabular}

As shown in Table7, the participants $(68.7 \%)$ generally agreed that they were quite satisfied with the language programs they undertook. However, they generally agreed with the rest of the statements in this section (the agreement percentage of each item range from $56 \%$ to $91 \%$ ).

7. Factors influence the views or attitudes to language program

To check whether such factors as participants' occupation, gender, age group, and years of teaching/studying were associated with their views on the intercultural awareness in Shanxi Provincial Universities, Mann-Whitney U tests or Kruskal-Wallis tests were performed on Q29, and Q33.

7.1 Influence of Participants' occupation on their response toQ29

TABLE8

PARTICIPANTS' RESPONSES TO Q29 CLASSIFIED BY OCCUPATION

\begin{tabular}{|l|l|l|l|l|l|l|l|}
\hline Participants' occupation & SA+A & NS & D+SD & Total & N & Rank Mean \\
\hline \multirow{2}{*}{ A(staff) } & count & 89 & 17 & 30 & 137 & \multirow{2}{*}{42} & \multirow{2}{*}{36.4} \\
\cline { 2 - 6 } & $\%$ of total & 27.5 & 5.2 & 9.3 & 42.0 & & \\
\hline \multirow{2}{*}{ B(student) } & count & 39 & 51 & 74 & 163 & \multirow{2}{*}{51} & \multirow{2}{*}{55.8} \\
\cline { 2 - 5 } & $\%$ of total & 11.9 & 15.6 & 22.7 & 50.2 & & \\
\hline
\end{tabular}

The result (Table8) showed that $65.5 \%((\mathrm{SA}+\mathrm{A}) / \mathrm{Total} \%)$ of staffs agreed that foreign students should be introduced to a language program, but only $23.7 \%((\mathrm{SA}+\mathrm{A}) / \mathrm{Total} \%)$ of students agreed, which meant participant's occupation influenced their view on Q29 significantly $(p<0.01)$, and the academic staffs much more firmly believed that oversea students should be introduced into a foreign language program.

7.2 Influence of staffs/students' gender, age, teaching/learning length on their response to Q29

TABLE9

PARTICIPANTS' RESPONSES TO Q29 CLASSIFIED BY GENDER

\begin{tabular}{|l|l|l|l|l|l|l|l|}
\hline Participants' gender & SA+A & NS & D+SD & Total & N & Rank Mean \\
\hline \multirow{2}{*}{ A(male) } & count & 62 & 36 & 55 & 152 & \multirow{2}{*}{47} & \multirow{2}{*}{40.8} \\
\cline { 2 - 6 } & $\%$ of total & 19.1 & 11 & 16.8 & 46.9 & & \\
\hline \multirow{2}{*}{$\mathrm{B}($ female $)$} & count & 66 & 32 & 49 & 147 & \multirow{2}{*}{46} & \multirow{2}{*}{44.9} \\
\cline { 2 - 6 } & $\%$ of total & 20.3 & 9.8 & 15.2 & 45.3 & & \\
\hline \multicolumn{2}{|l|}{ Mann-Whitney $U=1012.5$, Wilcoxon $W=2047.5, Z=0.377, p=0.706$} & \\
\hline
\end{tabular}

It was found there was no asymptotic significance $(p>0.05)$ between male $(40.8 \%)$ and female participants' agreement percentage (44.9\%), which meant the gender did not influence their response to Q29.

TABLE10

PARTICIPANTS' RESPONSES TO Q29 CLASSIFIED BY AGE GROUP

\begin{tabular}{|c|c|c|c|c|c|c|c|}
\hline \multicolumn{2}{|l|}{ Age group } & $\mathrm{SA}+\mathrm{A}$ & NS & $\mathrm{D}+\mathrm{SD}$ & Total & $\mathrm{N}$ & Rank mean \\
\hline \multirow{2}{*}{$A(18-22$ years $)$} & count & 27 & 17 & 20 & 64 & \multirow{2}{*}{20} & \multirow{2}{*}{45.7} \\
\hline & $\%$ of total & 8.2 & 5.1 & 6.3 & 19.6 & & \\
\hline \multirow{2}{*}{ B(23-30 years) } & count & 26 & 12 & 20 & 58 & \multirow{2}{*}{18} & \multirow{2}{*}{45.5} \\
\hline & $\%$ of total & 7.9 & 3.7 & 6.2 & 17.8 & & \\
\hline \multirow{2}{*}{ C(31-40 years) } & count & 26 & 13 & 20 & 59 & \multirow{2}{*}{19} & \multirow{2}{*}{45.5} \\
\hline & $\%$ of total & 8.0 & 4.1 & 6.1 & 18.2 & & \\
\hline \multirow{2}{*}{$\mathrm{D}(41-50$ years $)$} & count & 23 & 13 & 22 & 59 & \multirow{2}{*}{18} & \multirow{2}{*}{48.6} \\
\hline & $\%$ of total & 7.2 & 4.0 & 6.8 & 18.0 & & \\
\hline \multirow{2}{*}{$\mathrm{E}(51$ years +$)$} & count & 26 & 13 & 21 & 60 & \multirow{2}{*}{19} & \multirow{2}{*}{47.1} \\
\hline & $\%$ of total & 8.1 & 3.9 & 6.6 & 18.6 & & \\
\hline
\end{tabular}


Table 10 was the Kruskal-Wallis test result of Participants' response to Q29. It indicated that there were no asymptotic significance among the 4 age groups ( $p>0.05)$, which suggested that staffs' or students' age did not influence his/her opinion on whether foreign students should be introduced to a language program or not.

The analysis result (Table11) of participants' agreement percentage among different group classified by length of teaching/studying Chinese as foreign language revealed asymptotic significance $(p<0.01)$, which meant there was a significant association between the amount of teaching/studying years and his/her attitude to the language program. Then post Hoc multiple comparisons were performed to determine which group was significantly different from one another (Table12).

TABLE11

PARTICIPANTS' RESPONSES TO Q29 CLASSIFIED BY YEARS OF TEACHING/STUDYING

\begin{tabular}{|c|c|c|c|c|c|c|c|}
\hline \multicolumn{2}{|c|}{$\begin{array}{l}\text { Years of Chinese teaching/ studying } \\
\text { as foreign language }\end{array}$} & $\mathrm{SA}+\mathrm{A}$ & NS & $\mathrm{D}+\mathrm{SD}$ & Total & $\mathrm{N}$ & Rank mean \\
\hline \multirow{2}{*}{ A (0-1 year) } & count & 40 & 48 & 18 & 106 & \multirow{2}{*}{32} & \multirow{2}{*}{42.9} \\
\hline & $\%$ of total & 12.3 & 14.8 & 5.4 & 32.5 & & \\
\hline \multirow{2}{*}{ B(1-3 years) } & count & 14 & 15 & 38 & 66 & \multirow{2}{*}{21} & \multirow{2}{*}{59.4} \\
\hline & $\%$ of total & 4.3 & 4.5 & 11.6 & 20.4 & & \\
\hline \multirow{2}{*}{ C(3-5 years) } & count & 18 & 4 & 35 & 58 & \multirow{2}{*}{18} & \multirow{2}{*}{56.2} \\
\hline & $\%$ of total & 5.6 & 1.3 & 10.9 & 17.8 & & \\
\hline \multirow{2}{*}{$\mathrm{D}(5$ years +$)$} & count & 56 & 1 & 13 & 70 & \multirow{2}{*}{21} & \multirow{2}{*}{30.8} \\
\hline & $\%$ of total & 17.2 & 0.2 & 4.1 & 21.5 & & \\
\hline
\end{tabular}

Furthermore the result above showed that the agreement percentage of B and C groups (more than 1, but less than 5 years) were significantly higher than A(less than 1 year) and D (more than 5 years) group. It was inferred that novices $(<1$ year) or veterans ( $>5$ years) at foreign language teaching/studying did not care about the language program, while those who already passed the initial stage and involved in improvement phrase (2 5years) were much more interested in such program idea because they expected more intercultural theoretical target language application and practical experience. We might speculate the new Chinese teachers/learners probably focused on basic knowledge in the first year, not touched upon intercultural awareness yet, meanwhile the old hands in intensification phrase almost had unambiguous intercultural awareness and abundant intercultural conversation experience. It seemed that either too much or too little intercultural experience might reduce one's enthusiasm in language program.

TABLE12

THE POST HOC MULTIPLE COMPARISONS BETWEEN EVERY 2 GROUPS

\begin{tabular}{|l|l|l|l|l|l|l|l|}
\hline Group comparisons & Rank mean $_{1}$ & Rank mean & $\mathrm{N}_{1}$ & $\mathrm{~N}_{2}$ & $X^{2}$ & $d f$ & $p$ \\
\hline A vs B & 22.6 & 33.6 & 32 & 21 & 7.263 & 1 & 0.007 \\
\hline A vs C & 22.6 & 30.1 & 32 & 18 & 3.893 & 1 & 0.048 \\
\hline A vs D & 30.6 & 21.5 & 32 & 21 & 5.501 & 1 & 0.019 \\
\hline B vs C & 20.3 & 19.7 & 21 & 18 & 0.031 & 1 & 0.860 \\
\hline B vs D & 27.5 & 15.4 & 21 & 21 & 12.372 & 1 & 0.001 \\
\hline C vs D & 24.9 & 15.8 & 18 & 21 & 8.323 & 1 & 0.004 \\
\hline
\end{tabular}

7.3 Influence of staffs/students' gender, age, teaching/learning length on their response to Q33

The result (Table13) showed that there was significant difference between staff and student on the statement of Q33 $(p<0.01)$. 36.9\% ((SA+A)/Total\%) of the staffs and 67.3\% ((SA+A)/Total\%) of students agreed, while $61.4 \%$ of the staffs and $30.9 \%$ of students disagreed that the compulsory professional lecture should be taught in English other than Chinese. The possibility of difference was their attitude to the lecture language. It was inferred most of the staffs considered the professional lecture as an intercultural experience for foreign students too, so they persisted in that lectures should be taught in target language, while the majority of students thought the English lecture could be more easily for them to understand.

TABLE13

PARTICIPANTS' RESPONSES TO Q33 CLASSIFIED BY OCCUPATION

\begin{tabular}{|c|c|c|c|c|c|c|c|}
\hline \multicolumn{2}{|c|}{ Participants' occupation } & $\mathrm{SA}+\mathrm{A}$ & NS & $\mathrm{D}+\mathrm{SD}$ & Total & $\mathrm{N}$ & Rank mean \\
\hline \multirow{2}{*}{ A(staff) } & count & 63 & 3 & 104 & 170 & \multirow{2}{*}{52} & \multirow{2}{*}{55.9} \\
\hline & $\%$ of total & 19.3 & 0.9 & 32.1 & 52.3 & & \\
\hline \multirow{2}{*}{$\mathrm{B}$ (student) } & count & 96 & 3 & 44 & 143 & \multirow{2}{*}{45} & \multirow{2}{*}{41.0} \\
\hline & $\%$ of total & 29.6 & 0.8 & 13.6 & 44.0 & & \\
\hline
\end{tabular}

It was found from Table14 that there was no significant difference between male and female participants about their opinion on whether the compulsory professional classes should be taught in English or not $(p>0.05)$, which meant that gender was not a factor affected the responses to Q33. 
TABLE14

PARTICIPANTS' RESPONSES TO Q33 CLASSIFIED BY GENDER

\begin{tabular}{|c|c|c|c|c|c|c|c|}
\hline \multicolumn{2}{|c|}{ Participants' gender } & $\mathrm{SA}+\mathrm{A}$ & NS & $\mathrm{D}+\mathrm{SD}$ & Total & $\mathrm{N}$ & Rank mean \\
\hline \multirow{2}{*}{$\mathrm{A}($ male $)$} & count & 81 & 3 & 75 & 158 & \multirow{2}{*}{49} & \multirow{2}{*}{48.7} \\
\hline & $\%$ of total & 24.8 & 0.8 & 23 & 48.6 & & \\
\hline \multirow{2}{*}{$\mathrm{B}$ (female) } & count & 78 & 3 & 74 & 155 & \multirow{2}{*}{48} & \multirow{2}{*}{49.3} \\
\hline & $\%$ of total & 24.1 & 0.8 & 22.7 & 47.7 & & \\
\hline
\end{tabular}

The Table15 showed that there was no significant difference among different age groups' standpoint on whether the compulsory professional classes should be taught in English or not $(p>0.05)$, which meant that participants' age was not a factor impacted the responses to Q33 either.

TABLE15

PARTICIPANTS' RESPONSES TO Q33 CLASSIFIED BY AGE GROUP

\begin{tabular}{|c|c|c|c|c|c|c|c|}
\hline \multicolumn{2}{|l|}{ Age group } & $\mathrm{SA}+\mathrm{A}$ & NS & $\mathrm{D}+\mathrm{SD}$ & Total & $\mathrm{N}$ & Rank mean \\
\hline \multirow{2}{*}{$\mathrm{A}(18-22$ years $)$} & count & 32 & 2 & 29 & 64 & \multirow{2}{*}{20} & \multirow{2}{*}{48.6} \\
\hline & $\%$ of total & 9.9 & 0.7 & 9 & 19.6 & & \\
\hline \multirow{2}{*}{$\mathrm{B}(23-30$ years $)$} & count & 32 & 0 & 29 & 60 & \multirow{2}{*}{19} & \multirow{2}{*}{48.4} \\
\hline & $\%$ of total & 9.8 & 0 & 8.8 & 18.6 & & \\
\hline \multirow{2}{*}{$\mathrm{C}(31-40$ years $)$} & count & 32 & 1 & 30 & 63 & \multirow{2}{*}{19} & \multirow{2}{*}{48.5} \\
\hline & $\%$ of total & 9.7 & 0.4 & 9.2 & 19.3 & & \\
\hline \multirow{2}{*}{$\mathrm{D}(41-50$ years $)$} & count & 30 & 2 & 33 & 65 & \multirow{2}{*}{20} & \multirow{2}{*}{51.0} \\
\hline & $\%$ of total & 9.2 & 0.6 & 10.1 & 19.9 & & \\
\hline \multirow{2}{*}{$\mathrm{E}(51$ years +$)$} & count & 33 & 0 & 28 & 61 & \multirow{2}{*}{19} & \multirow{2}{*}{48.5} \\
\hline & $\%$ of total & 10.3 & 0 & 8.6 & 18.9 & & \\
\hline
\end{tabular}

The Table16 indicated that there was significant difference among different groups classified by the length of teaching/studying Chinese as foreign language $(p<0.01)$. Furthermore post Hoc multiple comparisons (Table17) were developed to reveal the relationship between amount of teaching or learning years and the point of view on intercultural awareness.

TABLE16

PARTICIPANTS' RESPONSES ON Q33 CLASSIFIED BY YEARS OF TEACHING/STUDYING

\begin{tabular}{|c|c|c|c|c|c|c|c|}
\hline \multicolumn{2}{|c|}{$\begin{array}{l}\text { Years of teaching/studying } \\
\text { Chinese as foreign language }\end{array}$} & \multirow{2}{*}{$\begin{array}{l}\mathrm{SA}+\mathrm{A} \\
76\end{array}$} & \multirow{2}{*}{$\begin{array}{l}\text { NS } \\
2\end{array}$} & \multirow{2}{*}{$\begin{array}{l}\mathrm{D}+\mathrm{SD} \\
24\end{array}$} & \multirow{2}{*}{$\begin{array}{l}\text { Total } \\
102\end{array}$} & \multirow{3}{*}{$\begin{array}{l}\mathrm{N} \\
32\end{array}$} & \multirow{3}{*}{$\begin{array}{l}\text { Rank mean } \\
37.1\end{array}$} \\
\hline \multirow{2}{*}{$\mathrm{A}(0-1$ year $)$} & count & & & & & & \\
\hline & $\%$ of total & 23.5 & 0.7 & 7.3 & 31.5 & & \\
\hline \multirow{2}{*}{ 1(B-3 years) } & count & 41 & 3 & 26 & 69 & \multirow{2}{*}{22} & \multirow{2}{*}{44.6} \\
\hline & $\%$ of total & 12.5 & 0.8 & 7.9 & 21.2 & & \\
\hline \multirow{2}{*}{$\mathrm{C}(3-5$ years $)$} & count & 31 & 1 & 33 & 65 & \multirow{2}{*}{20} & \multirow{2}{*}{50.3} \\
\hline & $\%$ of total & 9.6 & 0.2 & 10.1 & 19.9 & & \\
\hline \multirow{2}{*}{$\mathrm{D}(5$ years +$)$} & count & 11 & 0 & 66 & 77 & \multirow{2}{*}{23} & \multirow{2}{*}{68.5} \\
\hline & $\%$ of total & 3.3 & 0 & 20.4 & 23.7 & & \\
\hline
\end{tabular}

Obviously, the post Hoc multiple comparison of these 4 groups stated clearly that the response of every group was significantly different from another. From Table16 and 17, the agreement percentage $((S A+A) /$ Total\%: $74.6 \%$ of $A$ group, $58.9 \%$ of $B$ group, $48.2 \%$ of $C$ group, $13.9 \%$ of $D$ group agreed $)$ and disagreement percentage $((D+S D) /$ Total\%: 23.1\% of A group, 37.2\% of B group, 50.7\% of C group, 86.1\% of D group) of Q33 revealed an interesting and excited result that the longer taught/learned Chinese as a foreign language, the more Chinese classes they expected, because they wanted much more intercultural experience, and the Chinese professional lecture could be a potential to strengthen the intercultural communication capability.

TABLE17

THE POST HOC MULTIPLE COMPARISONS BETWEEN EVERY 2 GROUPS

\begin{tabular}{|l|l|l|l|l|l|l|l|}
\hline Group comparisons & Rank mean $_{1}$ & Rank mean & $\mathrm{N}_{1}$ & $\mathrm{~N}_{2}$ & $X^{2}$ & $d f$ & $p$ \\
\hline A vs B & 25.7 & 30.1 & 32 & 22 & 1.506 & 1 & 0.220 \\
\hline A vs C & 23.8 & 30.7 & 32 & 20 & 3.727 & 1 & 0.054 \\
\hline A vs D & 20.6 & 38.4 & 32 & 23 & 21.596 & 1 & 0.001 \\
\hline B vs C & 20.4 & 22.8 & 22 & 20 & 0.523 & 1 & 0.469 \\
\hline B vs D & 17.2 & 28.5 & 22 & 23 & 11.547 & 1 & 0.001 \\
\hline C vs D & 17.8 & 25.7 & 20 & 23 & 6.766 & 1 & 0.009 \\
\hline
\end{tabular}

Overall, the quantitative data analysis suggested that the survey which integrated cultural awareness into foreign language teaching and learning was valuable. In order to ascertain participants' views and attitudes to intercultural awareness in Chinese teaching/learning, influential factors and their statistical relationships to participants' responses were were studied by further qualitative data analysis. 


\section{B. Result and Qualitative Data Analysis}

As we all knew, semi-structured interviews was congruent with grounded theory methodology as it allowed the interviewee to talked about key questions from researcher well and truly, but also allowed flexibility and depth in questions exploration simultaneously, which could be in relation to the views or attitudes addressed in this study. So the qualitative comprehensible data from semi-structured interview was collected and analyzed in this part.

1. The interview questions design

The interview questions were designed to focus on the three aspects of objectives. Table18 showed the details of the specific interview question items and the objectives they addressed.

TABLE 18

RESEARCH OBJECTIVES AND QUESTION ITEMS

\begin{tabular}{|l|l|}
\hline Research objectives & Question items \\
\hline Views and attitude of staffs/students' intercultural awareness in general. & Open-ended section and Q1, Q2. \\
\hline Significance of intercultural awareness in Chinese teaching/learning & Q3, Q4 \\
\hline $\begin{array}{l}\text { Suggestions to enhance intercultural awareness and competence in } \\
\text { Shanxi Provincial university context. }\end{array}$ & Q4, Q5 \\
\hline
\end{tabular}

2 The interviewee background

A total of 25 respondents including 6 staffs and 19 foreign students who were working or studying at Shanxi Provincial Universities from July 2014 to June 2016 participated in semi-structured interviews. All 6 staff participants were native Chinese speaker. A total of 19 foreign students interviewed were from different countries, including American, Britain, Spanish, Italian, Ukraine, Russian, Armenia, Mexican, Nigeria, Uganda, Cameroon, Mongolia, Kazakhstan, Uzbekistan and Tajikistan. The demographic information of the interviewee participants were summarized in Table 19. And all interview participants were numbered.

TABLE19

DEMOGRAPHIC INFORMATION OF THE INTERVIEWEE PARTICIPANTS

\begin{tabular}{|c|c|c|c|c|c|}
\hline \multirow{2}{*}{\multicolumn{2}{|c|}{ Items }} & \multicolumn{2}{|c|}{ Staff participants(6) } & \multicolumn{2}{|c|}{ Student participants (19) } \\
\hline & & \multirow{2}{*}{$\begin{array}{l}\mathrm{n} / \mathrm{N} \\
4 / 6\end{array}$} & \multirow{2}{*}{$\begin{array}{l}\% \text { of total } \\
16\end{array}$} & \multirow{2}{*}{$\begin{array}{l}\mathrm{n} / \mathrm{N} \\
12 / 19\end{array}$} & \multirow{2}{*}{$\begin{array}{l}\% \text { of total } \\
48\end{array}$} \\
\hline & Male & & & & \\
\hline Gender & female & $2 / 6$ & 8 & $7 / 19$ & 28 \\
\hline \multirow{5}{*}{ Age } & $18-22$ years & $0 / 6$ & 0 & $6 / 19$ & 24 \\
\hline & 23-30 years & $1 / 6$ & 4 & $8 / 19$ & 32 \\
\hline & $31-40$ years & $3 / 6$ & 12 & $4 / 19$ & 16 \\
\hline & $41-50$ years & $2 / 6$ & 8 & $1 / 19$ & 4 \\
\hline & 51 years + & $0 / 6$ & 0 & $0 / 19$ & 0 \\
\hline \multirow{4}{*}{$\begin{array}{l}\text { Years of Chinese } \\
\text { teaching/learning as } \\
\text { foreign language }\end{array}$} & $0-1$ year & $0 / 6$ & 0 & $2 / 19$ & 8 \\
\hline & $1-3$ years & $2 / 6$ & 8 & $10 / 19$ & 40 \\
\hline & $3-5$ years & $3 / 6$ & 12 & $3 / 19$ & 12 \\
\hline & 5 years + & $1 / 6$ & 4 & $2 / 19$ & 8 \\
\hline
\end{tabular}

3. The themes analysis from interview

3.1 Theme 1: Views and attitudes of intercultural awareness.

The participants demonstrated their understanding of intercultural awareness from different perspectives: personal understanding, conceptualization, cultural background and social environment etc.

Basically, The intercultural awareness enabled people to interact effectively and acceptable to others in a group whose members had different cultural background (from staff4). Overall, To survive today's world, people should understand different culture, which could help people to adjust to unfamiliar environment they met, work, and live (from student 15). Adjustment and positive attitudes toward different cultures prompted people to take active roles in the diverse society' (from staff 2).

Meanwhile, racial discrimination is a sensitive and unavoidable issue that is commonly discussed within intercultural contexts. Some student participants from African mentioned their experience of being discriminated by other cultural background, which meant people's upbringing played an important role in their intercultural awareness.

One staff proposed that there are some cases in daily life in which we might highly motivated but lack the knowledge or the skills to communicate appropriately and effectively (from staff 6).

Besides, studying abroad is a recommendable way to promote one's intercultural competence.

I still find that it's only by studying a language that I began to seek more literature to read about that language and culture. (from Student 4)

Therefore, acquisition of intercultural competence, the capacity to change one's attitudes and behaviors to be open to other cultures, had become a critical issue to survive in globalized society.

3.2 Theme 2: Significance of intercultural awareness in foreign language teaching/studying.

It was found that there was not much difference between staffs and students on this concept. Moreover, there was a high agreement that language and culture were closely related that language was a special component of culture.

If seeing culture as an all-embracing general idea, language belong to the general culture of human being (from staff 4). A man with the capability of language must live in a language environment. To master a language, like Chinese, one 
must live in the very language cultural environment (from staff 5).

Obviously, it was inevitable to master Chinese, as a foreign language for international students, they should learn cultural structure of the language, besides expression or semantic meaning. And the teachers were the key for effective culture input, and they were not only language knowledge transmitters, but designer, organizer and participants of intercultural communication activities.

Teacher themselves should use every means available to enlarge their intercultural knowledge and help international students to familiarize the target language culture (from student 10).

once foreign students in anxiety of intercultural failure, they are easily to lose motivation of language study, so teacher should help them as much as possible to get out of intercultural dilemma. (from staff 4)

The important aspect proposed in this study was the foreigners' willingness to talk with the local people use target language. The majority of participants considered this as prerequisite to master target language.

It was amazing for me when I helped someone to use the telephone first time communicated with somebody not native to either of us. (from Student 9)

It was inferred that the cultural structure was the sum of all users of the language and life style of that nation, including geographic environments, folklore, fables, mythologies, social history development, customs, religious believes, values, science and technology, literature and art. Different cultures generated distinctive value system and perception of meaning. To be effective in target language-Chinese teaching/studying, the involved parties should be fully aware of the intercultural difference. Intercultural awareness enabled Chinese teacher and foreign students to modify their Chinese teaching/learning and communication patterns to be congruent with the cues of unfamiliar interaction parties. Change of teaching/studying and behavior would help them reach a mutual understanding.

3.3 Theme 3: suggestions to enhance intercultural awareness and competence in the context of Shanxi Provincial universities.

One purpose of this study was to collect suggestions of integration intercultural awareness into Chinese teaching/studying in Shanxi provincial Universities.

Chinese studying as a foreign language is so important for anyone wanted to communicate with Chinese, but try to keep in mind that language is more than a vehicle of communication. It teaches Chinese life style and pattern of interacting. (from student 12)

Chinese believe that talk has limitations and meaning resides beyond mere words. First, hidden meaning is highly desirable in Chinese culture. Second, language could influence manner in which you send and receive message from members of Chinese culture. (from staff 7)

Most of the interviewees approved that cultural component should ingrate into language course. Some creative ideas were put forward to enhance intercultural awareness and capability of teachers and students involved in Chinese teaching/studying.

I like the use of real life situations, reading short stories, chatting with native people. (from student 3)

The foreign students also suggested more cultural component in Chinese class, like 'language, society and culture', 'Literature in Chinese' and etc.

Teachers can use authentic materials, films, news broadcasts, magazines, newspapers, restaurant menus, travel brochures, and other printed materials. (from student 5)

Not only celebrating cultures of all types, but establishing critical views to develop students' critical intercultural awareness so that they will be able to accept all students in the Chinese class regardless of race, color, social class, age, sexual orientation, educational level, and ideology. (from staff 2)

In sum, most of participants focused on how to raise students' awareness on the importance of cultural topics and to help students become interested in the target culture. Teachers are called upon to find alternatives to help international students to reduce misrepresentations through more pertinent materials in which cultural conflicts, behaviors, and ideologies could be discussed. Through research program or development of class activities about language and culture, they could be able to instruct their students on intercultural awareness and communication competence and help them face the current process of globalization by creating an open atmosphere in classroom itself, where members surely from diverse backgrounds.

\section{DISCUSSION AND CONCLUSION}

The quantitative and qualitative data analysis of this research indicated that the intercultural awareness played an important role in Chinese teaching/studying as foreign language, which was recognized by most of teaching staffs and international students. The findings showed a strong correlation between intercultural experience, length of teaching/studying Chinese as foreign language and the enthusiasm in target language involved lectures or programs, regardless of age and gender. Their views and attitudes to intercultural awareness impacted target language and culture teaching and learning. The fact that cultural diversity, cultural misunderstanding or even conflicts unavoidable existed in Shanxi provincial universities should be understood and surmounted.

Intercultural awareness was in relation to particular contexts, and an awareness of the dynamic relationship between foreign language and its diverse social-cultural settings (Forsman, 2012). This study also suggested that the promotion of intercultural awareness among staffs as well as students to help international students take advantage of variety of 
opportunities available at campus or beyond to improve their effective intercultural communication. Much more intercultural strategies concentrated on improving target language proficiency and extending cultural experience in Chinese classes should be implemented or investigated to motivate students' intercultural enthusiasm through more positive learning environment, appropriated curriculum, further exploration, etc.

The great gift human have for each other was not an exotic experiences but an opportunity which could be accomplished only by interacting with others who did not share the same system (Messner, 2016). The advancement of intercultural communication capability depended on the motivating force to pursue communicative interaction. The process may or may not succeed but provided an opportunity to modify their skills in the developmental learning cycle, in which an in-depth awareness developed through on-going reflections, intercultural conversations, and understanding of cultural similarities and differences. Besides, the intercultural awareness and competence required not an awareness of cultural similarities but differences to enhance effective communication in a Chinese as foreign language classroom.

In sum, the development of oversea students' intercultural awareness and understanding recognized value of Chinese language teaching/learning as a resource to promote critical thinking about cultural assumptions and intercultural competence. Nonetheless, the teachers' motivation was pivotal to facilitating communication in culturally diverse classes. A cognitive willingness coupled with open-minded and positive attitude to manage intercultural difference, diversity or even conflict would contribute to target language and cultural mastery and application.

\section{Limitation OF THE STUDY}

The findings of this study were based on the views and perceptions of academic staff members and overseas students in the Shanxi Provincial universities. The number of participants was relatively small. Consequently, the respondents' attitudes were particular to this teaching/learning environment, and any attempt to generalize findings to other contexts should be careful. And further research could be conducted to explore more deep insights about how intercultural awareness and communication competence manifest in Chinese teaching/learning methodology and materials.

\section{ACKNOWLEDGEMENT}

I would like to express profound gratitude to Shanxi Scholarship Council of China (Project NO.2016-021) and Shanxi Provincial Education Department (Project NO. 2015210) for granting our research. Besides I am deeply grateful to the participants of this study, the teachers and students from the Colleges or Universities in Shanxi Province.

\section{APPENDIX I. QUESTIONNAIRE FOR ACADEMIC STAFF}

This questionnaire consists of two parts and is designed to collect data about your views and attitudes towards intercultural awareness. It takes about 10 minutes to complete it and your assistance will be deeply appreciated. If you are interested in participating in a 30 minutes' interview, please contact the researchers for further information.

Directions: Please put a check-mark $(\sqrt{ })$ on the item that applies to you or specify the information about yourself in the other category.

Part I: Demographic Information

1. Gender a. Male b. Female

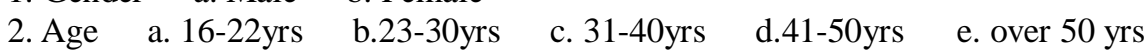

3. Chinese is your mother tongue

a. Yes b. No (please specify)

4. University at which you work

a. Shanxi University

b. Taiyuan Science \& Technology University

C. Shanxi Agriculture University

d. Taiyuan Normal University

e. Shanxi Finance and Economy University

5. Years of teaching Chinese as foreign language at this University
a. less than $1 \mathrm{yr}$
b. 1-3yrs
c. 3-5yrs
d. over 5 yrs

Part II: Please circle your most appropriate response.

Directions: Please indicate your most appropriate response by using the following criteria:

$\mathrm{SA}=$ Strongly Agree; $\quad \mathrm{A}=$ Agree; $\quad \mathrm{NS}=$ Not Sure; $\mathrm{D}=$ Disagree; $\quad \mathrm{SD}=$ Strongly Disagree 


\begin{tabular}{|c|c|c|c|c|c|}
\hline \multicolumn{6}{|l|}{ About China and world } \\
\hline Q6. China is a nation of cultural diversity now. & SA & A & NS & $\mathrm{D}$ & SD \\
\hline Q7. Intercultural awareness is important to China. & SA & A & NS & $\mathrm{D}$ & $\mathrm{SD}$ \\
\hline Q8. International students are an important source of intercultural awareness. & SA & A & NS & $\mathrm{D}$ & $\mathrm{SD}$ \\
\hline \multicolumn{6}{|l|}{ Personal intercultural experience } \\
\hline Q9. I like to interact with people from different cultural backgrounds. & SA & A & NS & $\mathrm{D}$ & $\mathrm{SD}$ \\
\hline Q10. I like eating food from other countries. & SA & A & NS & $\mathrm{D}$ & $\mathrm{SD}$ \\
\hline Q11. I like to travel overseas. & SA & A & NS & $\mathrm{D}$ & $\mathrm{SD}$ \\
\hline \multicolumn{6}{|l|}{ Aspect of intercultural awareness } \\
\hline Q12. Intercultural awareness enriches one's life. & SA & A & NS & $\mathrm{D}$ & $\mathrm{SD}$ \\
\hline Q13. Intercultural awareness widens one's worldview. & SA & A & NS & $\mathrm{D}$ & SD \\
\hline Q14. Intercultural awareness enhances understanding of one's own culture. & SA & A & NS & $\mathrm{D}$ & $\mathrm{SD}$ \\
\hline Q15. Intercultural awareness enhances world peace. & SA & A & NS & $\mathrm{D}$ & SD \\
\hline Q16. Intercultural awareness is hard to develop. & SA & A & NS & $\mathrm{D}$ & $\mathrm{SD}$ \\
\hline Q17. Travel enhances intercultural awareness. & SA & $\mathrm{A}$ & NS & $\mathrm{D}$ & $\mathrm{SD}$ \\
\hline Q18. Interacting with migrants enhances intercultural awareness. & SA & A & NS & $\mathrm{D}$ & $\mathrm{SD}$ \\
\hline Q19. Interacting with international students enhances intercultural awareness & SA & A & NS & $\mathrm{D}$ & $\mathrm{SD}$ \\
\hline Q20. The internet plays an important role in intercultural awareness. & SA & A & NS & $\mathrm{D}$ & $\mathrm{SD}$ \\
\hline \multicolumn{6}{|l|}{ Intercultural awareness and language teaching } \\
\hline Q21. Learning Chinese involves learning its culture. & SA & A & NS & $\mathrm{D}$ & $\mathrm{SD}$ \\
\hline $\begin{array}{l}\text { Q22 Cultural component provides meaningful context for Chinese language } \\
\text { course. }\end{array}$ & SA & A & NS & $\mathrm{D}$ & $\mathrm{SD}$ \\
\hline Q23. Cultural components enhances students' motivation towards target language. & SA & A & NS & $\mathrm{D}$ & $\mathrm{SD}$ \\
\hline Q24. Cultural component promotes students' curiosity about Chinese language. & SA & A & NS & $\mathrm{D}$ & $\mathrm{SD}$ \\
\hline Q25. Cultural component does not impede students' Chinese acquisition. & SA & A & NS & $\mathrm{D}$ & $\mathrm{SD}$ \\
\hline \multicolumn{6}{|l|}{ Intercultural awareness and course design } \\
\hline Q26. Culture should be part of Chinese language course. & SA & A & NS & $\mathrm{D}$ & $\mathrm{SD}$ \\
\hline Q27. Culture should be integrated into Chinese teaching. & SA & A & NS & $\mathrm{D}$ & $\mathrm{SD}$ \\
\hline $\begin{array}{l}\text { Q28. Students in a language program should be introduced to native Chinese } \\
\text { speaker. }\end{array}$ & SA & A & NS & $\mathrm{D}$ & SD \\
\hline Q29. Foreign students should be introduced to a Chinese language program. & SA & A & NS & $\mathrm{D}$ & $\mathrm{SD}$ \\
\hline $\begin{array}{l}\text { Q30. Textbooks in a language program should be written by native Chinese } \\
\text { speakers. }\end{array}$ & SA & A & NS & $\mathrm{D}$ & $\mathrm{SD}$ \\
\hline Q31. Translation should be avoided in language teaching. & SA & $\mathrm{A}$ & NS & $\mathrm{D}$ & $\mathrm{SD}$ \\
\hline $\begin{array}{l}\text { Q32. Apart from textbooks, there are other useful resources for teaching in } \\
\text { Chinese language program. }\end{array}$ & SA & A & NS & $\mathrm{D}$ & $\mathrm{SD}$ \\
\hline $\begin{array}{l}\text { Q33. Some compulsory professional course should be taught in English, other } \\
\text { than Chinese. }\end{array}$ & SA & A & NS & $\mathrm{D}$ & $\mathrm{SD}$ \\
\hline \multicolumn{6}{|l|}{ Personal experience in language program } \\
\hline Q34. The Chinese language program I have taught is too theoretical. & SA & A & NS & $\mathrm{D}$ & $\mathrm{SD}$ \\
\hline $\begin{array}{l}\text { Q35. The Chinese language program I have taught pays little attention to the } \\
\text { culture. }\end{array}$ & SA & A & NS & $\mathrm{D}$ & $\mathrm{SD}$ \\
\hline $\begin{array}{l}\text { Q36. The Chinese language program I have taught deals adequately with } \\
\text { intercultural awareness. }\end{array}$ & SA & A & NS & $\mathrm{D}$ & $\mathrm{SD}$ \\
\hline $\begin{array}{l}\text { Q37. The Chinese language program I have taught helps me to appreciate other } \\
\text { cultures. }\end{array}$ & SA & A & NS & $\mathrm{D}$ & $\mathrm{SD}$ \\
\hline $\begin{array}{l}\text { Q398. The Chinese language program I have taught inspires me to interact with } \\
\text { people of different cultures. }\end{array}$ & SA & A & NS & $\mathrm{D}$ & $\mathrm{SD}$ \\
\hline $\begin{array}{l}\text { Q39. The Chinese language program I have taught enhances my intercultural } \\
\text { awareness. }\end{array}$ & SA & A & NS & D & $\mathrm{SD}$ \\
\hline
\end{tabular}

\section{Any other relevant information you wish to add?}

\section{APPENDIX II. QUESTIONNAIRE FOR OVERSEA STUDENTS}

This questionnaire consists of two parts and is designed to collect data about your views and attitudes towards intercultural awareness. It takes about 10 minutes to complete it and your assistance will be deeply appreciated. If you are interested in participating in a 30 minutes' interview, please contact the researchers for further information.

Directions: Please put a check-mark $(\sqrt{ })$ on the item that applies to you or specify the information about yourself in the other category.

Part I: Demographic Information

1. Gender a. Male b. Female

2. Age a. $16-22 \mathrm{yrs} \quad$ b. $23-30 \mathrm{yrs} \quad$ c. $31-40 \mathrm{yrs} \quad$ d. $41-50 \mathrm{yrs} \quad$ e. over $50 \mathrm{yrs}$

3. English is your mother tongue

a. Yes b. No (please specify)

4. University in which you study right now

a. Shanxi University 
b. Taiyuan Science \& Technology University

C. Shanxi Agriculture University

d. Taiyuan Normal University

e. Shanxi Finance and Economy University

5. Years of learning Chinese as foreign language in this University

$\begin{array}{llll}\text { a. less than } 1 \mathrm{yr} & \text { b. 1-3yrs } & \text { c. } 3-5 y r s & \text { d. over } 5 \text { yrs }\end{array}$

Part II: Please circle your most appropriate response.

Directions: Please indicate your most appropriate response by using the following criteria:

$\mathrm{SA}=$ Strongly Agree; $\quad \mathrm{A}=$ Agree; $\quad \mathrm{NS}=$ Not Sure; $\mathrm{D}=$ Disagree $\quad \mathrm{SD}=$ Strongly Disagree

\begin{tabular}{|c|c|c|c|c|c|}
\hline \multicolumn{6}{|l|}{ About China and world } \\
\hline Q6. China is a nation of cultural diversity now. & SA & $\mathrm{A}$ & NS & $\mathrm{D}$ & SD \\
\hline Q7. Intercultural awareness is important to China. & SA & A & NS & $\mathrm{D}$ & SD \\
\hline Q8. International students are an important source of intercultural awareness. & SA & A & NS & $\mathrm{D}$ & SD \\
\hline \multicolumn{6}{|l|}{ Personal intercultural experience } \\
\hline Q9. I like to interact with people from different cultural backgrounds. & SA & A & NS & $\mathrm{D}$ & SD \\
\hline Q10. I like eating food from other countries. & SA & A & NS & $\mathrm{D}$ & SD \\
\hline Q11. I like to travel overseas. & SA & $\mathrm{A}$ & NS & $\mathrm{D}$ & SD \\
\hline \multicolumn{6}{|l|}{ Aspect of intercultural awareness } \\
\hline Q12. Intercultural awareness enriches one's life. & SA & A & NS & $\mathrm{D}$ & SD \\
\hline Q13. Intercultural awareness widens one's worldview. & SA & A & NS & $\mathrm{D}$ & SD \\
\hline Q14. Intercultural awareness enhances understanding of one's own culture. & SA & A & NS & $\mathrm{D}$ & SD \\
\hline Q15. Intercultural awareness enhances world peace. & SA & A & NS & $\mathrm{D}$ & SD \\
\hline Q16. Intercultural awareness is hard to develop. & SA & A & NS & $\mathrm{D}$ & SD \\
\hline Q17. Travel enhances intercultural awareness. & SA & A & NS & $\mathrm{D}$ & $\mathrm{SD}$ \\
\hline Q18. Interacting with migrants enhances intercultural awareness. & SA & A & NS & $\mathrm{D}$ & SD \\
\hline Q19. Interacting with international students enhances intercultural awareness & SA & A & NS & $\mathrm{D}$ & SD \\
\hline Q20. The internet plays an important role in intercultural awareness. & SA & $\mathrm{A}$ & NS & $\mathrm{D}$ & SD \\
\hline \multicolumn{6}{|l|}{ Intercultural awareness and language teaching } \\
\hline Q21. Learning Chinese involves learning its culture. & SA & $\mathrm{A}$ & NS & $\mathrm{D}$ & SD \\
\hline $\begin{array}{l}\text { Q22 Cultural component provides meaningful context for Chinese language } \\
\text { course. }\end{array}$ & SA & A & NS & $\mathrm{D}$ & SD \\
\hline Q23. Cultural components enhances students' motivation towards target language. & SA & A & NS & $\mathrm{D}$ & SD \\
\hline Q24. Cultural component promotes students' curiosity about Chinese language. & SA & A & NS & $\mathrm{D}$ & SD \\
\hline Q25. Cultural component does not impede students' Chinese acquisition. & SA & A & NS & $\mathrm{D}$ & SD \\
\hline \multicolumn{6}{|l|}{ Intercultural awareness and course design } \\
\hline Q26. Culture should be part of Chinese language course. & SA & A & NS & $\mathrm{D}$ & SD \\
\hline Q27. Culture should be integrated into Chinese teaching. & SA & A & NS & $\mathrm{D}$ & SD \\
\hline $\begin{array}{l}\text { Q28. Students in a language program should be introduced to native Chinese } \\
\text { speaker. }\end{array}$ & SA & A & NS & $\mathrm{D}$ & SD \\
\hline Q29. Foreign students should be introduced to a Chinese language program. & SA & A & NS & $\mathrm{D}$ & SD \\
\hline $\begin{array}{l}\text { Q30. Textbooks in a language program should be written by native Chinese } \\
\text { speakers. }\end{array}$ & SA & A & NS & $\mathrm{D}$ & SD \\
\hline Q31. Translation should be avoided in language teaching. & SA & $\mathrm{A}$ & NS & $\mathrm{D}$ & SD \\
\hline $\begin{array}{l}\text { Q32. Apart from textbooks, there are other useful resources for teaching in } \\
\text { Chinese language program. }\end{array}$ & SA & A & NS & $\mathrm{D}$ & SD \\
\hline $\begin{array}{l}\text { Q33. Some compulsory professional course should be taught in English, other } \\
\text { than Chinese. }\end{array}$ & SA & A & NS & $\mathrm{D}$ & $\mathrm{SD}$ \\
\hline \multicolumn{6}{|l|}{ Personal experience in language program } \\
\hline Q34. The Chinese language program I have learned is too theoretical. & SA & A & NS & $\mathrm{D}$ & SD \\
\hline $\begin{array}{l}\text { Q35. The Chinese language program I have learned pays little attention to the } \\
\text { culture. }\end{array}$ & SA & A & NS & $\mathrm{D}$ & SD \\
\hline $\begin{array}{l}\text { Q36. The Chinese language program I have learned deals adequately with } \\
\text { intercultural awareness. }\end{array}$ & SA & A & NS & $\mathrm{D}$ & SD \\
\hline $\begin{array}{l}\text { Q37. The Chinese language program I have learned helps me to appreciate other } \\
\text { cultures. }\end{array}$ & SA & A & NS & $\mathrm{D}$ & SD \\
\hline $\begin{array}{l}\text { Q398. The Chinese language program I have learned inspires me to interact with } \\
\text { people of different cultures. }\end{array}$ & SA & A & NS & $\mathrm{D}$ & SD \\
\hline $\begin{array}{l}\text { Q39. The Chinese language program I have learned enhances my intercultural } \\
\text { awareness. }\end{array}$ & SA & A & NS & $\mathrm{D}$ & SD \\
\hline
\end{tabular}

\section{Any other relevant information you wish to add?}

APPENDIX III. VIEWS AND ATtITUdES OF STAFFS AND OVERSEA STUDENTS TOWARDS THE SignifiCANCE OF INTERCULTURAL AwARENESS IN FOREIGN LANGUAGE TEACHING AND LEARNING IN SHANXI PROVINCIAL UNIVERSITIES CONTEXT 


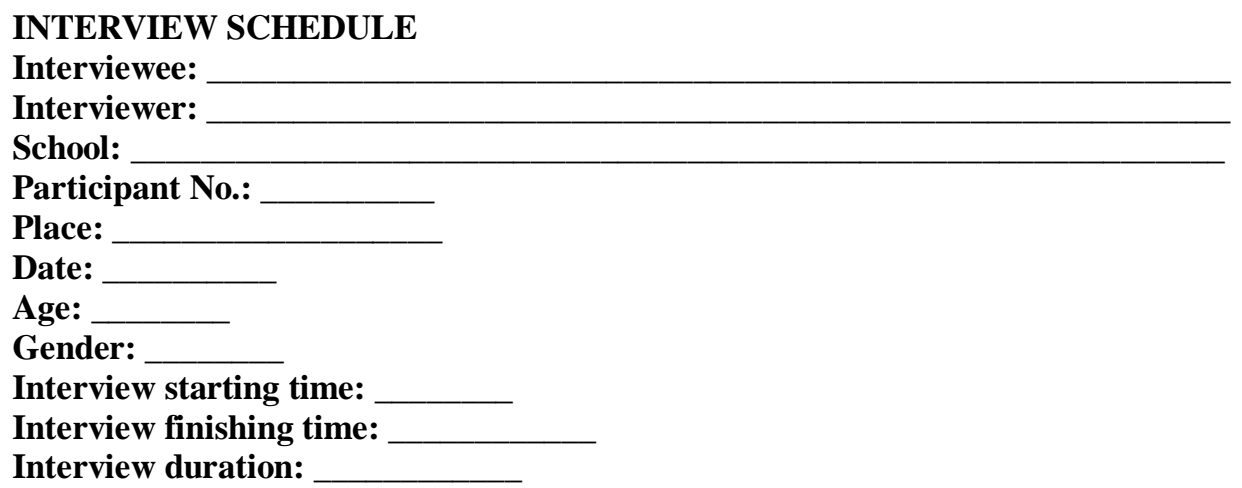

There are 5 questions. Please feel free to give as much detail as you wish in your answers. If you are unclear about the meaning of any question, please ask for clarification.

1 Do you think studying abroad could improve the intercultural competence?

2 What are the important factors could impact personal intercultural awareness and capability?

3 What did the Chinese teaching/studying as foreign language change your intercultural awareness and capability?

4 What should the teacher do in Chinese teaching as foreign language to enlarge students' cultural background?

5 How could the universities or colleges improve staffs' or students' intercultural awareness and capability?

This concludes the questions for the interview. Thank you very much for your cooperation.

\section{REFERENCES}

[1] Australia Bureau of Statistics. (2013). Cultural diversity in Australia, 2071.0 - Reflecting a nation: Stories from the 2011 Census, 2012-2013. Retrieved March $\quad$ 5, 2013, from http://www.abs.gov.au/ausstats/abs@.nsf/Lookup/2071.0main+features902012-2013.

[2] Baker, W. (2012). From cultural awareness to intercultural awareness: Culture in ELT. ELT Journal, 66(1), 62-70.

[3] Bodycott, P., \& Lai, A. (2012). The influence and implications of Chinese culture in the decision to undertake cross-border higher education. Journal of Studies in International Education, 16(2), 252-270.

[4] Chinese National Development and Reform Commission. (2015). Vision and Actions on Jointly Building Silk Road Economic Belt and 21st-Century Maritime Silk Road. https://www.douban.com/note/491223644/.

[5] Colvin, C., Volet, S. \& Fozdar, F. (2013). Local university students and intercultural interactions: Conceptualizing culture, seeing diversity and experiencing interactions. Higher Education Research \& Development, 33 (3), 440-455.

[6] Forsman, L. (2012). Investigating the cultural dimension in foreign language education from transmission of facts to dialogic uptake. Education Action Research, 20(4):483-496.

[7] Leask, B. (2009). Using formal and informal curricula to improve interactions between home and international students. Journal of Studies in International Education, 13(2), 205-221.

[8] Leung, A., \& Chiu, C. (2010). Multicultural experience, idea receptiveness, and creativity. Journal of Cross-Cultural Psychology, 41(5), 723-741.

[9] Likert, R. (1932). A technique for the measurement of attitudes. New York: Archives of psychology.

[10] Mak, A. S. (2010). Enhancing academics' capability to engage multicultural classes and internationalize at home. International Journal of Teaching and Learning in Higher Education, 22(3), 365-373.

[11] Matsumoto, D., \& Yoo, S. H. (2006). Toward a new generation of cross-cultural research. Perspectives on Psychological Science, $1,234-250$.

[12] Messner, W. (2016). Measuring existent intercultural effectiveness in global teams. Journal for Multicultural Education, 10(1): 33-52.

[13] Paul, D., Geoffrey, R., \& Darin, W. (2006). The language of social science: a brief introduction. Talk and interaction in social research methods (pp. 1-6). London: Athenaeum press.

[14] Petrakis, P. E., \& Kostis, P.C. (2013). Economic Growth and Cultural Change. Journal of Socio-Economics, 47: $147-157$.

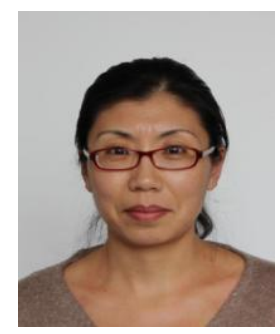

Junqing Wang is an assistant professor in the College of International Education and Communication, Shanxi University. Her research concerns structures and strategies of spoken discourse, conversation analysis, and inter-culture communication issues involved in foreign language and education. One of her current research program is focused on conversation strategies between native-Chinese teacher and non-native-Chinese students in classes to ensure the pedagogical tasks to be accomplished efficiently. The other study program is to develop the academic staffs as well as oversea students' intercultural competence in Chinese teaching/learning as foreign language to provide intercultural strategies to motivate target culture enthusiasm and foreign language proficiency. 